\title{
The Mitla Landslide, an Event That Changed the Fate of a Mixteco/Zapoteco Civilization in Mesoamerica
}

\author{
V. H. Garduño-Monroy $\mathbb{D}^{1},{ }^{1}$ A. Figueroa-Soto, ${ }^{2}$ N. Magaña-García, ${ }^{3}$ A. Ruiz-Figueroa, ${ }^{4}$ \\ J. Gómez-Cortés, ${ }^{4}$ A. Jiménez-Haro, ${ }^{3}$ and V. M. Hernández-Madrigal ${ }^{1}$ \\ ${ }^{1}$ UMSNH-INICIT-MGPT, Edificio U Ciudad Universitaria, Morelia, Mich., Mexico \\ ${ }^{2}$ CONACyT-Instituto de Investigaciones en Ciencias de la Tierra, UMSNH, Mexico \\ ${ }^{3}$ GEMEX, Mexico \\ ${ }^{4} M G Y P T-U M S N H$, Mexico
}

Correspondence should be addressed to V. H. Garduño-Monroy; vhgardunom@gmail.com

Received 26 November 2018; Revised 6 February 2019; Accepted 24 March 2019; Published 2 May 2019

Academic Editor: Marek Grad

Copyright (c) 2019 V. H. Garduño-Monroy et al. This is an open access article distributed under the Creative Commons Attribution License, which permits unrestricted use, distribution, and reproduction in any medium, provided the original work is properly cited.

Before the arrival of the Spanish conquerors, Mitla was the second most important city in the valleys of Oaxaca, México. However, the ruins that are visible today do not seem to match the size of a city of more than 10,000 inhabitants. Geological and geophysical studies suggest that part of the city was covered by the deposits of a dry landslide likely to have been caused by an earthquake with a magnitude that could vary between 6 and 7. This landslide is monolithological, which is why two geophysical methods were used in order to evaluate its geometrical characteristics and to suggest the possible existence of archeological remains under the landslide.

\section{Introduction}

Many hypotheses regarding the collapse of Mesoamerican cultures have been linked to wars, conquests, epidemics, or climate changes. However, Mesoamerica is located in a context presenting exceptional seismic, volcanic, and meteorological phenomena. Past and current events in México (Tehuantepec, Pinotepa Nacional or Morelos-Puebla earthquakes $\sim \mathrm{M} 8$, SSN) indicate that tsunamis, earthquakes, and volcanic eruptions countered the development of many important civilizations. For instance, the collapse of Maya culture is insistently related to a large drought, yet very few theories associate these human extinctions with exceptional events. Much of this disaster information was written in the codices. These documents contain data with place and time specifications, also providing information on natural disaster scenarios. For example, in the Telleriano-Remensis codex, tlacuilos recorded approximately 12 seismic events that include glyphs that suggest a scale of environmental effects that appears similar to ESI2007 [1].

The location of Mesoamerica compels us to think that those cultures witnessed very important seismic and volcanic events. For instance, the birth of the Tarascan empire is clearly linked to changes in the landscape due to an earthquake and to the birth of Capaxtiro volcano [2]. Besides the areas towered by volcanos, earthquakes caused important imbalances or prophecies, such as the fourth bad omen described by León Portilla [3], which warned the Aztecs about the arrival of the Spanish conquerors (The burning lake, El Lago en Llamas): "Texcoco Lake burned, its boiling waters swelled and swept the houses, killing many". This description is certainly very close to an account of the formation of a tsunami caused by an earthquake.

On the other hand, the ongoing seismic activity in the State of Oaxaca brought about a particular architectural practice: in order to resist violent earthquakes, the churches have very thick walls, huge buttresses, and short towers (Figure 1).

The study of the effects of important earthquakes can be carried out according to different environmental or anthropogenic results. In present case the research focuses on the geophysical analysis of the Mitla Landslide. As in this case the collapse was caused by an earthquake, the techniques selected were ground-penetrating radar and electrical tomography 


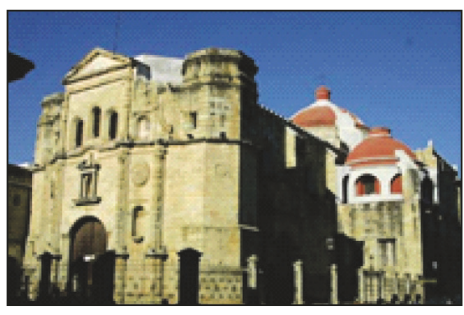

(a)

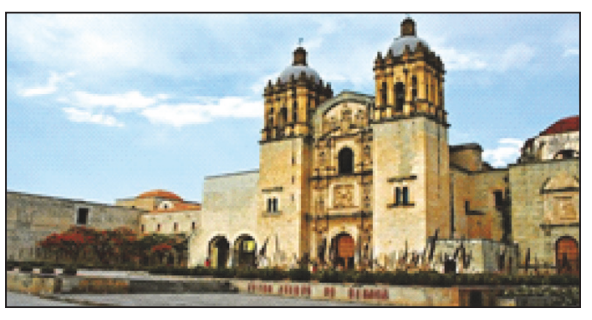

(b)

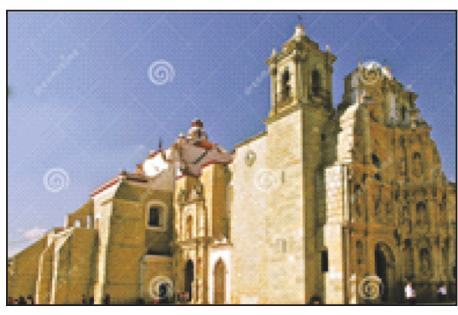

(c)

Figure 1: Churches in Oaxaca City feature short towers and huge buttresses. (a) La Compañía Church, (b) Church of Santo Domingo, and (c) Basílica of Our Lady of Solitude.

and cross- correlations of seismic ambient noise records. The two last were those that yielded the best results. Eventually the use of the radar was not a good option due to the homogeneity of the landslide and for the little penetration of this, which in this case is monolithologic. Conversely, electrical tomography was an adequate method. The use of seismic noise and the advantage of a regional earthquake register allowed us to find a clear lithological contrast.

\section{Tectonic Setting of Oaxaca}

Oaxaca is one of the major earthquake zones of México, due to the Cocos plate subduction under the North American plate and the seismic activity related to intraplate structure that causes shallow quakes, such as the Xalapa earthquake of 1920. Oaxaca has been affected by a large number of seismic events with magnitudes above 7 (Table 1, data provided by the Servicio Sismológico Nacional (SSN), UNAM 2018), so much so that Fray Juan de Córdova's Vocabulario en lengua zapoteca (1578) contains words to designate the tremor of the earth: xoo, but also a name for the deity of earthquakes: Pitao xoo.

Beside subduction earthquakes, Oaxaca presents intraplate faulting related to the limits of tectonic terranes expressed in the Central and Tehuacan valleys. The Central valleys of Oaxaca are part of the Oaxaca fault system, which is formed at the borders between the Zapoteco and Cuicateco terranes (Figure 2(a)), and besides its normal component has always been thought to have a horizontal component in arguable direction (Figure 2(c), [4].

The seismicity reported by the Servicio Sismológico Nacional (SSN) and presented in Figure 2(c) corresponds to the intraplate events zone in the south-east zone of México named by Zúñiga et al. [5] as NAM and matches the intraplate seismicity of the southeastern zone of México that is not related to the volcanism of the Trans Mexican Volcanic Belt; its maximum depth has been measured at $20 \mathrm{~km}$.

The focal mechanisms presented in Figure 2(b) correspond to quakes of magnitude over 7 and were taken from the IRIS (Incorporated Research Institution for Seismology) consortium. Most of these focal mechanisms are associated with the zone of strong coupling between the Cocos and North American tectonic plates (interplate, reverse faulting) and others to rupture processes of the subducted Cocos plate (normal faulting).

Recently, in 2017 and 2018, major events occurred again in Oaxaca, the first on September 7 with magnitude $8.2 \mathrm{Mw}$ and epicenter located in the Gulf of Tehuantepec, $137 \mathrm{~km}$ southeast of Pijijiapan (Chiapas), and $46 \mathrm{~km}$ deep. This event is mainly related to normal faulting $\left(79^{\circ} \mathrm{dip}\right)$ that caused the complete rupture of the lithosphere in a zone related to the seismic gap of Tehuantepec, in which no event of this magnitude had taken place since 1787 , when an earthquake of $\mathrm{Mw} \approx 8.6$ occurred [6].

The second event happened on Friday February 16, 2018, of magnitude $7.2 \mathrm{Mw}$ and epicenter $11 \mathrm{~km}$ from Pinotepa Nacional, Oaxaca. Both events caused material and human losses.

It is important to mention that regarding recurrence periods for the central zone of the State of Oaxaca, Zúñiga et al. [5] report periods of 6 years for quakes with magnitudes above 5 occurring in the NAM zone (shallow events with depth under $20 \mathrm{~km}$ ), periods of 109 years for magnitudes above 7 taking place within the subducted Cocos plate (intraplate events with depths of 40 to $180 \mathrm{~km}$ ), and periods of 37 years for quakes of magnitudes above 7.5 occurring in the coupling zone of the Cocos and North American tectonic plates (subduction area).

On the other hand, previous refraction and reflection studies across the Oaxaca fault $[7,8]$ did not confirm that it runs as deep as presumed. Supporting this result, the regional magnetotelluric study by Jödicke [9] did not detect the expected large electric contrast across the Oaxaca fault at crustal depths along a transect passing south of Oaxaca City. By analyzing the electrical impedance along a regional transect, Jording et al. [10] concluded that the major structural change at depth in this region is displaced northeastwards of the Mitla Valley, about $30 \mathrm{~km}$ east from the generally accepted Oaxaca-Juárez terrane boundary. A more detailed MT study of the region [11] concluded that the Oaxaca fault system does not appear to penetrate deep into the crust but remains relatively shallow $(5 \mathrm{~km})$. Other results [12] also suggest that the contact between the Oaxaca and Juarez terranes at crustal depths occurs along a SW-dipping interface south of Oaxaca City [13].

\section{Study Zone and Landslide}

The town of Mitla is located south of Oaxaca City $\left(16^{\circ} 55^{\prime} 41.3^{\prime \prime}-96^{\circ} 21^{\prime} 33.8^{\prime \prime}-1706 \mathrm{~m}\right.$ a.s.1.) in a vale of $\mathrm{NW}$ SE orientation. It presents evident morphological contrasts that have molded Precambrian, Tertiary, and current rocks, thereby forming sierra and valleys in the same direction, and 
TABLE 1: Earthquakes above M7 in Oaxaca from 1787 to 2018 (Servicio Sismológico Nacional, UNAM 2018).

\begin{tabular}{|c|c|c|c|c|c|}
\hline Year & Month & Day & Magnitude & Depth & Reference \\
\hline 1787 & 3 & 28 & 8.6 & $?$ & $\begin{array}{c}\text { Tehuantepec Ridge. } \\
\text { Tsunami in the Coast of } \\
\text { Oaxaca }\end{array}$ \\
\hline 1916 & 6 & 2 & 7 & 150.0 & $\begin{array}{l}42 \mathrm{~km} \text { south of SAYULA } \\
\text { DE ALEMAN, VER }\end{array}$ \\
\hline 1928 & 3 & 21 & 7.5 & 33.0 & $\begin{array}{l}12 \mathrm{~km} \text { southeast of } \\
\text { CRUCECITA, OAX }\end{array}$ \\
\hline 1928 & 6 & 16 & 7.6 & 33.0 & $\begin{array}{c}11 \mathrm{~km} \text { west of } \\
\text { MIAHUATLAN, OAX }\end{array}$ \\
\hline 1928 & 8 & 4 & 7.4 & 33.0 & $\begin{array}{l}49 \mathrm{~km} \text { south of } \mathrm{H} \\
\text { TLAXIACO, OAX }\end{array}$ \\
\hline 1928 & 10 & 8 & 7.5 & 33.0 & $\begin{array}{c}35 \mathrm{~km} \text { northeast of RIO } \\
\text { GRANDE, OAX }\end{array}$ \\
\hline 1931 & 1 & 15 & 7.4 & 40.0 & $\begin{array}{c}30 \mathrm{~km} \text { west of } \\
\text { MIAHUATLAN, OAX }\end{array}$ \\
\hline 1937 & 12 & 23 & 7.4 & 33.0 & $\begin{array}{c}46 \mathrm{~km} \text { southwest of } \mathrm{H} \\
\text { TLAXIACO, OAX }\end{array}$ \\
\hline 1948 & 1 & 6 & 7 & 80.0 & $\begin{array}{c}45 \mathrm{~km} \text { southeast of } \mathrm{H} \\
\text { TLAXIACO, OAX }\end{array}$ \\
\hline 1950 & 12 & 14 & 7.2 & 33.0 & $\begin{array}{c}47 \mathrm{~km} \text { west of } \mathrm{H} \\
\text { TLAXIACO, OAX }\end{array}$ \\
\hline 1951 & 12 & 11 & 7 & 100.0 & $\begin{array}{c}59 \mathrm{~km} \text { east of MATIAS } \\
\text { ROMERO, OAX }\end{array}$ \\
\hline 1965 & 8 & 23 & 7.5 & 12.0 & $\begin{array}{l}53 \mathrm{~km} \text { northeast of } \\
\text { CRUCECITA, OAX }\end{array}$ \\
\hline 1968 & 8 & 2 & 7.3 & 16.0 & $\begin{array}{c}39 \mathrm{~km} \text { northeast of } \\
\text { PINOTEPA NACIONAL, } \\
\text { OAX }\end{array}$ \\
\hline 1973 & 8 & 28 & 7.3 & 82.0 & $\begin{array}{c}30 \mathrm{~km} \text { southwest of } \\
\text { TIERRA BLANCA, VER }\end{array}$ \\
\hline 1978 & 11 & 29 & 7.6 & 23.0 & $\begin{array}{c}32 \mathrm{~km} \text { northwest of S } \\
\text { PEDRO POCHUTLA, } \\
\text { OAX }\end{array}$ \\
\hline 1980 & 10 & 24 & 7.1 & 65.0 & $\begin{array}{c}19 \mathrm{~km} \text { west of ACATLAN } \\
\text { DE OSORIO, PUE }\end{array}$ \\
\hline 1982 & 6 & 7 & 7 & 19.0 & $\begin{array}{l}20 \mathrm{~km} \text { southeast of } \\
\text { OMETEPEC, GRO }\end{array}$ \\
\hline 1995 & 9 & 14 & 7.3 & 21.0 & $\begin{array}{l}29 \mathrm{~km} \text { northeast of } \\
\text { OMETEPEC, GRO }\end{array}$ \\
\hline 1996 & 2 & 24 & 7.1 & 15.0 & $\begin{array}{c}52 \mathrm{~km} \text { south of PINOTEPA } \\
\text { NACIONAL, OAX }\end{array}$ \\
\hline 1999 & 6 & 15 & 7 & 63.0 & $\begin{array}{c}29 \mathrm{~km} \text { southwest of S } \\
\text { GABRIEL CHILAC, PUE }\end{array}$ \\
\hline 1999 & 9 & 30 & 7.4 & 39.0 & $\begin{array}{c}22 \mathrm{~km} \text { northeast of } \\
\text { PUERTO ESCONDIDO, } \\
\text { OAX }\end{array}$ \\
\hline 2012 & 3 & 20 & 7.5 & 18.0 & $\begin{array}{c}46 \mathrm{~km} \text { south of } \\
\text { OMETEPEC, GRO }\end{array}$ \\
\hline 2017 & 9 & 7 & 8.2 & 45.9 & $\begin{array}{l}140 \mathrm{~km} \text { southwest of } \\
\text { PIJIJIAPAN, CHIS }\end{array}$ \\
\hline 2017 & 9 & 19 & 7.1 & 38.5 & $\begin{array}{c}9 \mathrm{~km} \text { northeast of } \\
\text { CHIAUTLA DE TAPIA, } \\
\text { PUE }\end{array}$ \\
\hline 2018 & 2 & 16 & 7.2 & 12.0 & $\begin{array}{c}11 \mathrm{~km} \text { south of PINOTEPA } \\
\text { NACIONAL, OAX }\end{array}$ \\
\hline
\end{tabular}




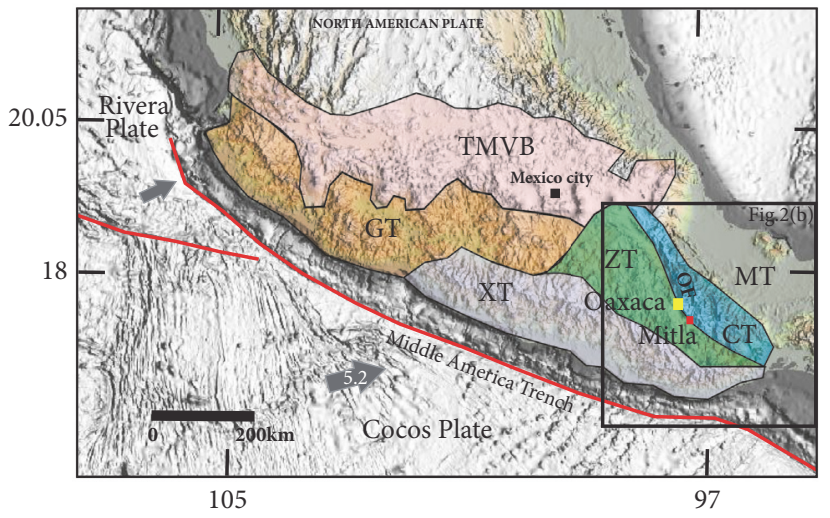

(a)

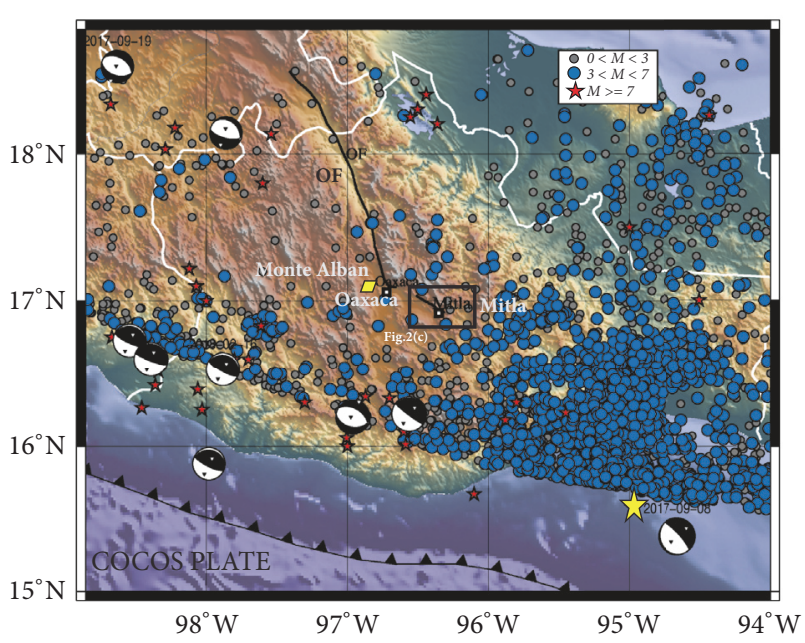

(b)

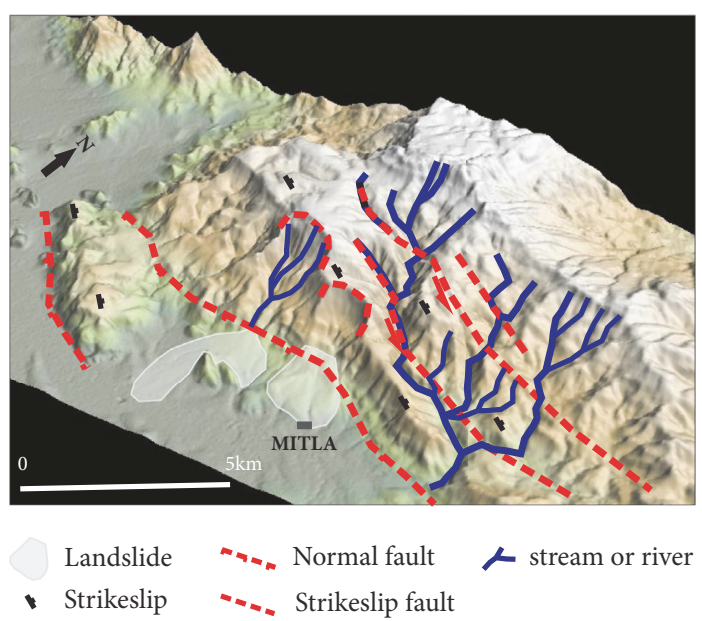

(c)

FIgure 2: (a) Tectonic scheme of the south of México: TMVB (Transmexican Volcanic Belt), GT (Guerrero Terrane), ZT (Zapoteco Terrane), XT (Xolapa Terrane), CT (Cuicateco Terrane), MT (Maya Terrane), OF (Oaxaca Fault). (b) Seismicity reported by SSN with depths between 0 and $20 \mathrm{~km}$ deep and (c) structural scheme of the Mitla area in Oaxaca.

where sometimes the N-S drainage system is modified by NW-SE structures (Figure 2(c)).

The word Mitla or Mictlán is nahuátl and means "Place of the Dead" or "Underworld". In Zapotec it is called Lyobaa which means: "place of graves" or "place of burials", from the etymology Lio: Place and Baa: grave or burial [14]; in mexica it remained Mictlán, "Place of the Dead", or "place of many corpses", and was hispanicized to Mitla. Contrary to Monte Albán, the heyday of Mitla occurred between 950 and $1521 \mathrm{AD}$. The settlements of Mitla have been estimated to be over $7,000 \mathrm{~km}^{2}$ large, with a population of around 10,000 inhabitants. One of its main characteristics are constructions decorated with elaborate mosaic fretwork (grecas) featuring variations of the same geometric design, and the crossshaped tombs that have been found under the palaces, in which important people and priests were probably buried. The archeological complex includes several structures, two of which were covered with Christian buildings, the most important of which was constructed in 1590. The San Pablo church was erected in one of the prehispanic courts of Mitla using stones from the temples themselves. The basic architectural form of the few pyramids shows paraseismic techniques, visible both in the Las Columnas site as in the Grupo Arroyo, where notches appear in the frames of all the entrances to the rooms.

During our field work the avalanche deposit was identified for the first time in all the surroundings of the archeological remains of San Pablo Villa de Mitla. Previous works mapped the avalanche as part of pyroclasts deposits [15]. Its distal facies seem to have covered part of the pyramids, as shown hereunder and on Figure 3.

\section{Methodology}

The methodology of this study focused on 5 main guidelines: (a) the first step was to find previous research on Mitla in the fields of Archeology and Geosciences; (b) subsequently, a $50 \mathrm{~cm}$-definition terrain model was mapped with a drone; (c) 


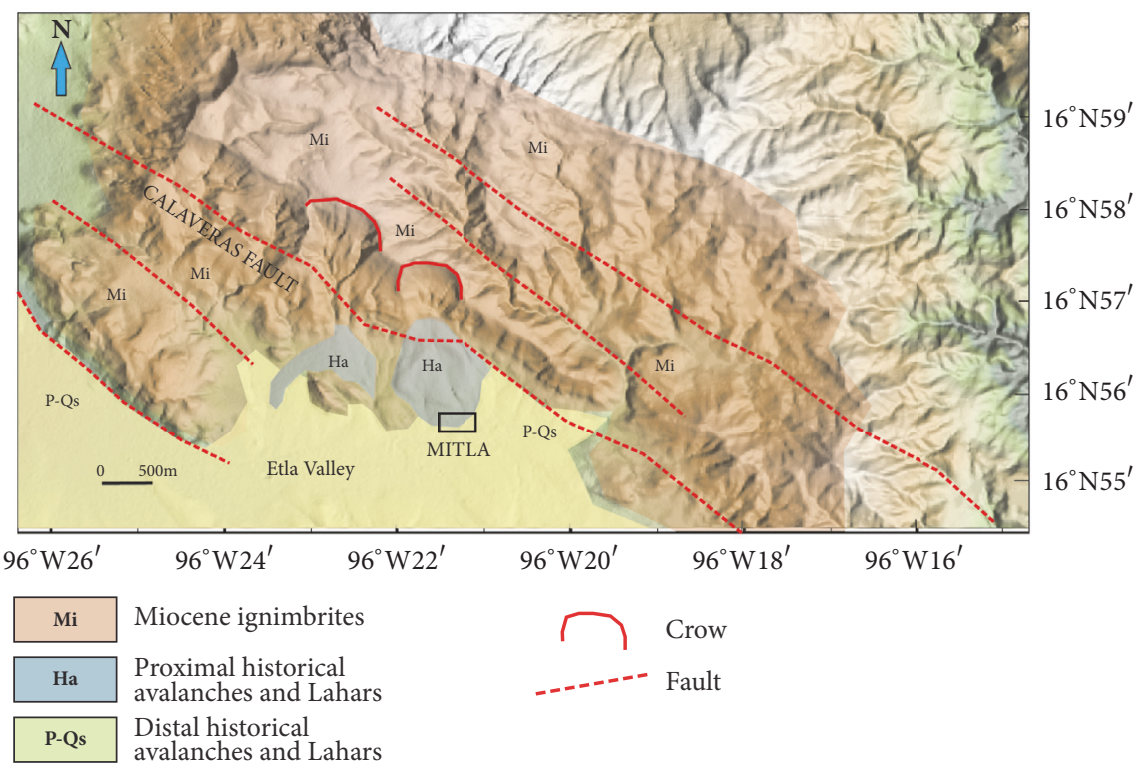

(a)

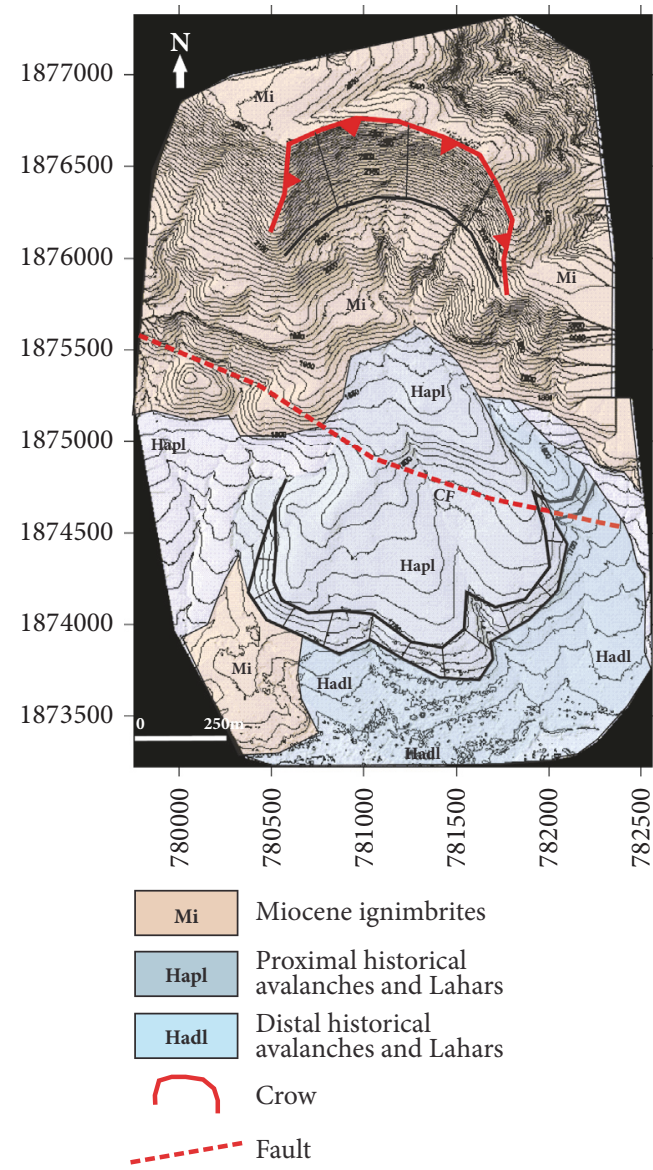

(b)

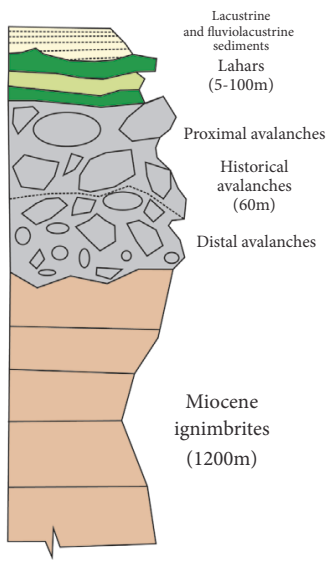

(c)

Figure 3: (a) Regional geology of the valley of Etla. (b) Geology of the Mitla Avalanche. (c) Synthesis of the lithological column of Mitla. 
geology and all the data regarding geophysical, morphostructural; (d) stratigraphical characterization, structural geology in the Sierra Calaveras and (e) the geomechanical study of the landslide were based upon this model.

Various columns were extracted from the landslide to study its geology. Once the lithology was understood, the area was mapped in detail.

Several methodologies were applied regarding geophysics, such as ground-penetrating radar (Mala) and electrical and seismic tomography. The first method was not adequate due to insufficient penetration and scarce lithological contrast. The seismic and electrical tomographies, however, yielded valuable results.

Reconnaissance methods, which mainly include remotesensing and aerial techniques, geological and geomorphological mapping, and geophysical and geotechnical techniques, had to be adapted to the characteristics of the landslide. According to McCann and Foster [16], a geotechnical appraisal of the landslide's stability has to consider the three following issues: (1) the definition of the 3D geometry of the landslide with particular emphasis on failure surfaces, (2) the definition of the hydrogeological regime, and (3) the detection and characterization of the movement.

The method for seismicity was to obtain velocity profiles using horizontal-to-vertical spectral ratios ( $\mathrm{H} / \mathrm{V}$ ratios) of microtremors $[17,18]$ named Nakamura method, and inversion with the Spatial Auto-correlation Method [19] and with the $\mathrm{H} / \mathrm{V}$ [20] based on ambient noise measurements carried out with 3 long-period Trillium Compact 120s sensors with frequency responses of $120 \mathrm{~s}$ to $100 \mathrm{~Hz}$, and their respective RefTek 130S three channel and 24 bits-resolution third generation recorders. Regarding microtremors, it was taken into account that the energy sources are multidirectional [18]; thus, the direction of maximum movement is unknown. Moreover, the use of this kind of technique does not cause environmental impact and yields precise results.

Microtremors, also called ambient vibration noise, seismic microtremors, or background seismic noise, are random vibrations generated by natural or artificial sources. The aim of the Nakamura method and the SPAC technique was to determine velocity profiles in the northern region of the archeological zone of Mitla in order to determine the depth of the base of the landslide.

The H/V technique was developed by [18] and is used for obtaining direct estimates of site-specific response during an earthquake (e.g., [21, 22]), with relating geological and geophysical properties of Wells together with seismic records analysis on the various geological site conditions. It was hypothesized that the vertical component of the ambient noise at the ground surface keeps the characteristics of basement ground, is relatively influenced by Rayleigh wave on the sediments, and can therefore be used to remove both the source and the Rayleigh wave effects from the horizontal components. It is effective in identifying the fundamental resonance frequency of a sedimentary layer, where the depth $H$ of a soft soil layer with resonance frequency $F$ and shear wave velocity $V$ s is given by $H=V \mathrm{~s} /(4 * F)$.

The H/V spectral ratio of microtremors measured anywhere confirmed its ability to estimate the predominant frequency and the amplification factor. The result of the estimation is stable for the measured time and season (Nakamura, 1989).

The seismic noise records were visually inspected to select signals that are complete and that had a good signal-to-noise ratio. Two software packages were used for data processing: SAC (Seismic Analysis Code) and Geopsy (Geophysical Signal Database for Noise Array Processing) (SESAME WP05) [23]. The results of these programs were compared because they have a different smoothing function in obtaining $\mathrm{H} / \mathrm{V}$ [24].

$\mathrm{H} / \mathrm{V}$ spectral ratios were calculated for the three components of each record. This was done automatically when estimating the H/V ratio with the Geopsy software. For the calculation of $\mathrm{H} / \mathrm{V}$ for each selected window, a smoothing function was applied with a bandwidth coefficient of $\mathrm{b}=$ 40 and a 5\% cosine taper-window. This type of smoothing function employs a different number of points at low and high frequency; its use is strongly recommended for frequency analysis [25].

Using the SAC (Seismic Analysis Code) software, spectral ratios were determined in 81.92 seconds windows and a smoothing with a Von Hann window [26]. The results of both programs did not show significant differences.

The method known as SPAC (spatial autocorrelation method) was first introduced in 1957 by [27]. The SPAC method considers the dispersive characteristics of surface waves in a stratified medium [28]. When only the vertical component of seismic noise record is used, we can easily assume that the signal has a high content of Rayleigh waves.

In this method, it is proposed that from simultaneous microtremor measurements in some geometric arrangements of seismic stations, it is possible to obtain the dispersion curve by calculating the coefficient of spatial autocorrelation [29].

We represent harmonic wave circular microtremor frequency $\omega$ by $\mathrm{u}(0,0, \omega, \mathrm{t})$ and $\mathrm{u}(\mathrm{r}, \theta, \omega, \mathrm{t})$, which are observed in the center $\mathrm{C}(0,0)$ of the array and point $\mathrm{X}(\mathrm{r}, \theta)$ on the circle of radius $r$. Then spatial autocorrelation function is defined as

$$
\varphi(r, \theta, \omega)=\overline{u(0,0, \omega, t) u(r, \theta, \omega, t)}
$$

where $u(t)$ is the average value in the time domain. The spatial autocorrelation coefficient for one angular frequency $\omega, \mathrm{p}$ $(\omega, \mathrm{r})$, or simply autocorrelation coefficient is defined as the power spectrum of one station within a spatial arrangement (middle circle):

$$
\rho(f, r)=J_{0}\left(\frac{2 \pi f r}{c(f)}\right)
$$

Therefore, the spatial autocorrelation coefficient at a frequency $f$ is related to the phase velocity $c(f)$ through the Bessel function of first kind and zero order $J_{0}$. The phase velocity calculated from the argument of the Bessel function generated (2). For the SPAC technique, we used Geopsy software [23]. Prior to making rings, correlation graphs were generated, and the dispersion curve was then adjusted.

Seismic noise measurements were taken during two days on the archeological site of Mitla. For each day, a triangular 


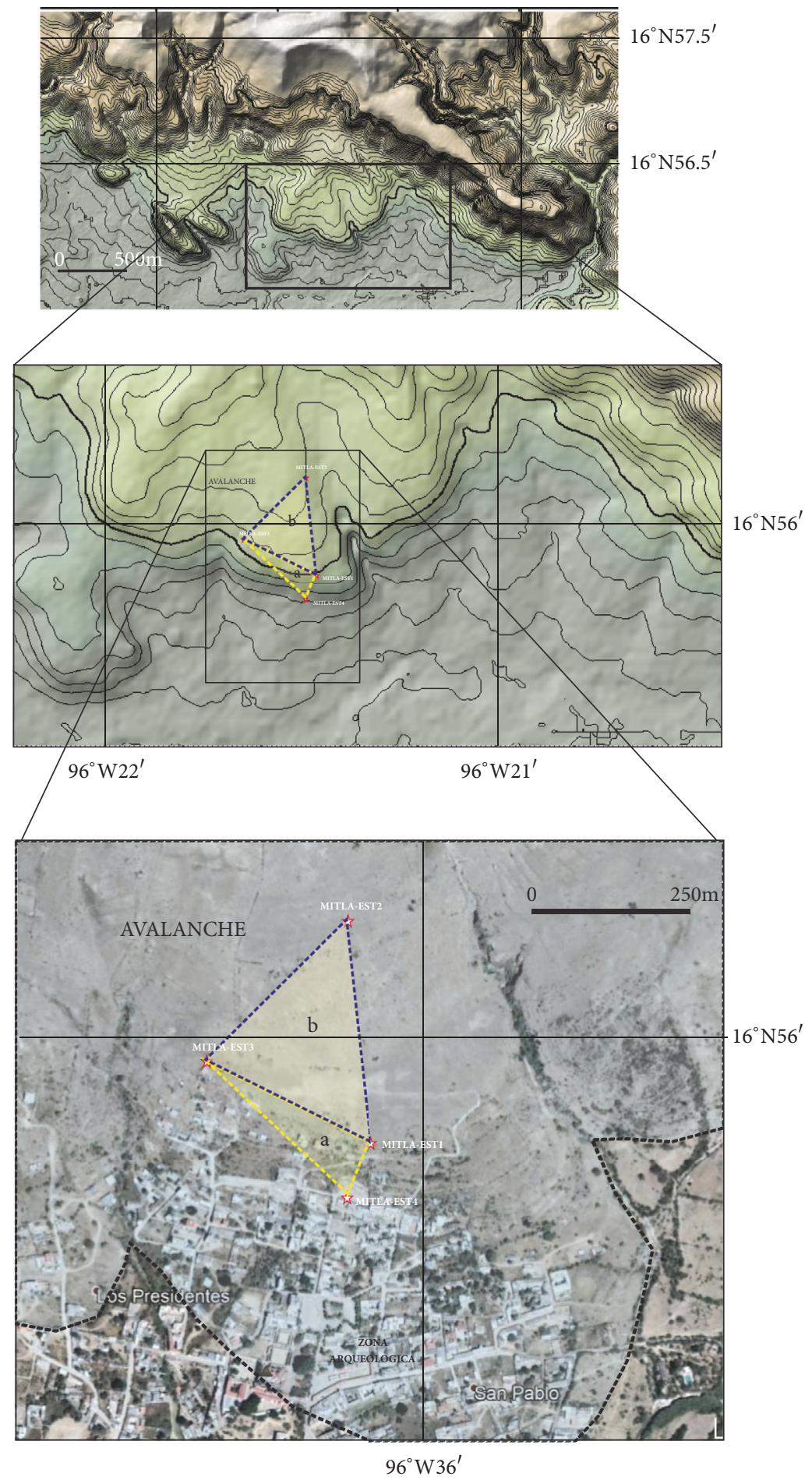

FIgURE 4: (a) Seismic array \# 1 and (b) seismic array \# 2.

array with three seismic stations and with seismic records with durations of 10 hours (array 1) and 6 hours (array 2) was built (Figure 4).

\section{Geoelectrical Tomography}

Geoelectrical imaging is geophysical technique that was developed on the basis of physical methods that are helpful to reveal the presence or absence of buried bodies and structures that cannot be seen with the naked eye, but that can be detected because of their distinctive physical properties of being resistive to their surroundings (e.g., [30-32].

The aim of geoelectrical mappings is to determine the distribution of resistivity in the subsoil through measurements carried out on the surface. The true resistivity of the subsoil can be estimated from these measurements. In this 
sense, the resistivity of the earth is related to geological parameters according to its mineral content, fluid saturation, and rock porosity. Geoelectrical studies have been used for some decades now for hydrological and mining research and for geotechnical research. However, more recently, these methods have become more sophisticated in mapping the subsoils, and they have increasingly been used to locate structures and characterize the subsoil.

The aim of this study is to obtain a 2D model of true resistivities from the pseudosection of apparent resistivities obtained from the field. This is why an inversion program is necessary.

On the other hand, samples of the landslide sediments were submitted to granulometric analysis and evaluation of their petrophysical properties. Unfortunately, neither organic soils, nor pieces of carbon were found to date the landslide.

\section{Results}

6.1. Geology of the Mitla Area. The stratigraphical column of the Mitla zone is composed of a basement of Precambrian rocks from the Zapoteco terrane covered by Mesozoic carbonated units veiled by pyroclastic flows that constitute Sierra La Calavera. On these sequences and on the hanging wall, huge Pleistocene lacustrine basins developed as part of the large valleys of the study zone, which are actually the hanging wall of the normal NNW-SSE fault carved by other faults following the same direction and which could be responsible for the Mitla Landslide (Figure 3).

The main structures are oriented NNW-SSE and clearly present the geometry of normal faults with strik-slip sinistral component. This fault, which we henceforth call Calaveras fault, is part of the large structures that are the boundaries of the tectonic terranes, especially those that limit the Zapoteco and Cuicateco terranes (Figures 2 and 3 ).

The ignimbrite sequence of rhyolitic composition is formed of at least two large packages; the inferior package corresponds to the hanging wall of the normal Calavera or Mitla fault outcropping at La Fortaleza and Mitla (Figure 3). The second is the package of Sierra La Calavera and is made of at least 4 thick ignimbrite packages, some of which are welded and others crumblier, but all with Q, PL, and mica crystals; some levels are tightly welded at different points of the column. These were dated between $14.4 \pm 0.4 \mathrm{My}$ and $15.48 \pm 0.2 \mathrm{My}$, Miocene [15].

Above the ignimbrites of the hanging wall of the La Calavera fault is a thick landslide deposit formed of different levels but nonetheless of monolithologic composition, i.e., formed only of block and rhyolitic rocks matrix. The blocks range from gravel to blocks of more than $5 \mathrm{~m}$ in diameter, some of which are angular and others semirounded. More data regarding this landslide will be given hereunder.

On top of the landslide and the ignimbrites are lahar deposits, varying from blocks and matrix to hyperconcentrated lahars.

Fluviolacustrine deposits were observed in río Mitla formed by conglomerates, sands and clays, all of which heavily faulted. Large Pleistocene vertebrates were reportedly discovered in these deposits [15].
6.2. Geometry of the Collapses and Description of the Deposits. In a detailed elevation model, two large landslide flows can be seen opening towards the south in the Sierra La Calavera, which is formed by tabular deposits of ignimbrites tilted towards the north. Because of its provenance, the most visible of the flows is the Mitla Landslide. This wide scarp and deposit bundle is clearly observable and delimited. The main scarp has a maximum diameter of $1350 \mathrm{~m}$ and a slope relief of $390 \mathrm{~m}$. The landslide ran over more than $2500 \mathrm{~m}$ from the basis of the main scarp to the toe. The second main scarp, located NNO of Mitla, is less regular, both in its main scarp and in its body (Figure 5). Both main scarps are located within the footwall of the normal fault that caused the Mitla depression.

6.3. Geomechanics and Granulometry. An average per size was obtained, of samples from the avalanche front, from the granulometric data using the sizes of the wire mesh cloth of the sieves used to observe the behavior of one granulometry (Figure 6). As in the case of individual strata, the line does not break, which reveals a fair distribution of the material and very little space among particles.

6.3.1. $\Phi$ Value. With an elevation model presenting curve details every $50 \mathrm{~cm}$, we obtained the value of the $\mathrm{H} / \mathrm{L}$ relation for a length (L) of $1.633 \mathrm{~km}$, and a drop height of $0.640 \mathrm{~km}$, yielding $\Phi=0.39$, which means its value is characteristic of dry landslides, i.e., of 0.5 .

6.4. Slope Mobility. Reference [33] introduced an indicator regarding the mobility of slopes called excessive travel distance. This parameter (Le) expresses the horizontal distance traveled in excess by the event, superior to what could be expected if the movement was that of a nonlubrified event of rigid mass, which would move across a tilted plane with a normal coefficient of friction of $\tan \left(32^{\circ}\right)$.

$$
\begin{aligned}
& \mathrm{Le}=\mathrm{L}-\left(\frac{\mathrm{H}}{0.62}\right) \\
& \mathrm{Le}=1033
\end{aligned}
$$

As can be observed, the distance covered in excess indicates the movement of the body in the specific conditions mentioned above, and comparing it with the true distance of the slope we can observe that the difference is small, indicating scarcity of water. In cases wherein, water is presented as triggering factor; the difference can be four times higher.

6.5. Geophysics. In order to know the geometry of the landslide, three $2 \mathrm{D}$ tomography lines were acquired with $\mathrm{a}=4 \mathrm{~m}$ (Figure 8). The vertical resolution obtained was of $2 \mathrm{~m}$ and the horizontal resolution of $4 \mathrm{~m}$. Lines 1 and 2 were $108 \mathrm{~m}$ long with NE-SW orientation. Line 3 was $156 \mathrm{~m}$ long and oriented SE-NW (Figure 7).

Data obtained so far reveal a landslide body of low resistivities (11-17) in blue and in the southern part of the profiles, between 4 and 5 meters from the ground, there is a body of average resistivity (22) colored green and yellow, interpreted as part of the ignimbrite basement or possible remains of pyramids constructed with ignimbrites. 


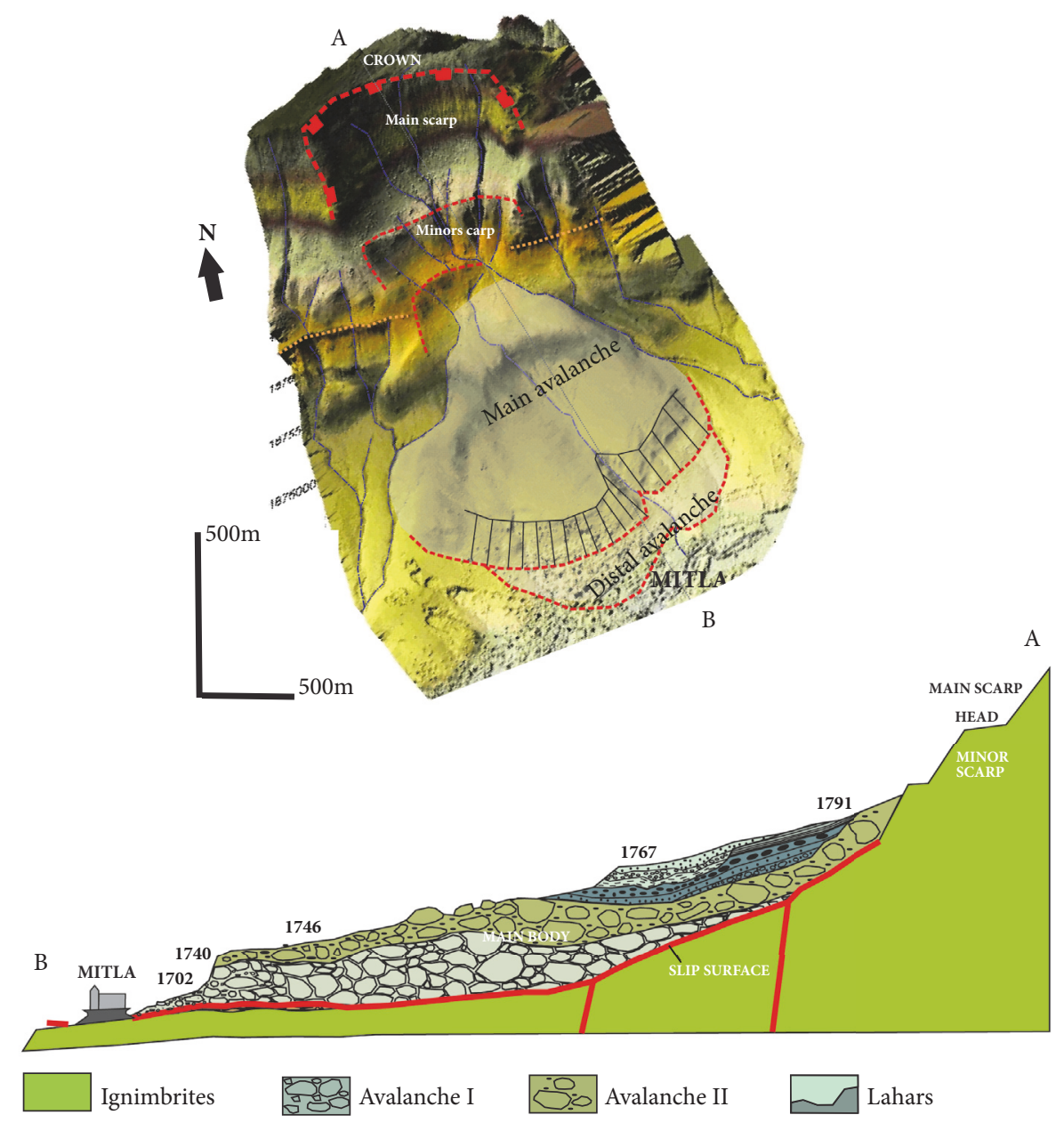

Figure 5: Map of the landslide and profile showing the different deposits. (A) The 3D terrain model which is exaggerated in the vertical 2 times. (B) is a schematic field section with heights above sea level (m a.s.l.).

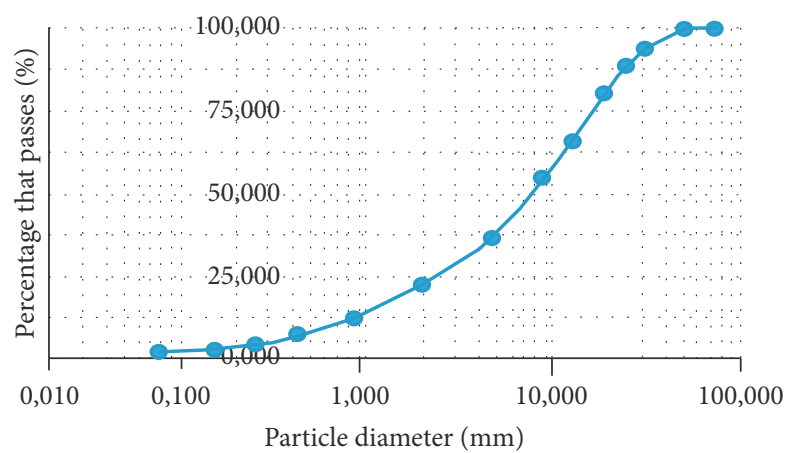

FIGURE 6: Average of granulometries of the 5 strata of the landslide in each of the sieves used for the analysis.

6.6. Seismic Noise Records. On the assumption that the derived dispersion function represents the first mode of the Rayleigh waves, we derived a best-fitting velocity model that is consistent with the estimated velocity values. Figures 8 and 9 show the Rayleigh waves dispersion function for each seismic array.
6.7. Inversion of the $H / V$ Spectral Ratio. Figure 10 presents the $\mathrm{H} / \mathrm{V}$ spectral ratio for stations 1 and 3 for seismic array \# 1 . Here, the H/V rotate tool was used to obtain the H/V in the horizontal plane, i.e., as azimuth function, from any type of 3D vibration signals (ambient vibrations, earthquakes, etc.). The black curve represents $\mathrm{H} / \mathrm{V}$ geometrically averaged over all individual colored $\mathrm{H} / \mathrm{V}$ curves. The two dashed lines represent the $\mathrm{H} / \mathrm{V}$ standard deviation. The grey area represents the average peak frequency and its standard deviation. The frequency value is at the limit between the dark grey and light grey areas. The parameters were frequency sampling from $1 \mathrm{~Hz}$ to $15 \mathrm{~Hz}$, global time range from $\mathrm{T} 0$ to the end of the time series and time windows to $81.92 \mathrm{~s}$.

The inversion of the spectral ratios allows us to obtain a velocity profile for each measurement site. In Table 2 we show the fundamental frequencies for each seismological station and the classification of the type of soil associated with the site based on the NEHRP (National Earthquake Hazards Reduction Program) classification [34].

It was determined that the depth of the base of the landslide is of 50 meters below array 1 (region south of the 
(a)

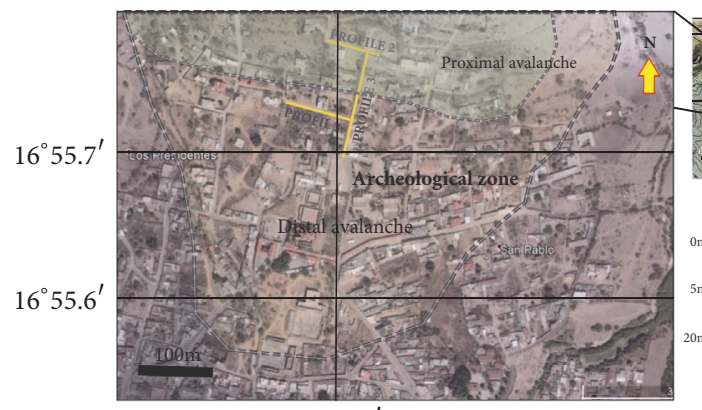

$91^{\circ} 21.5^{\prime}$

(c)

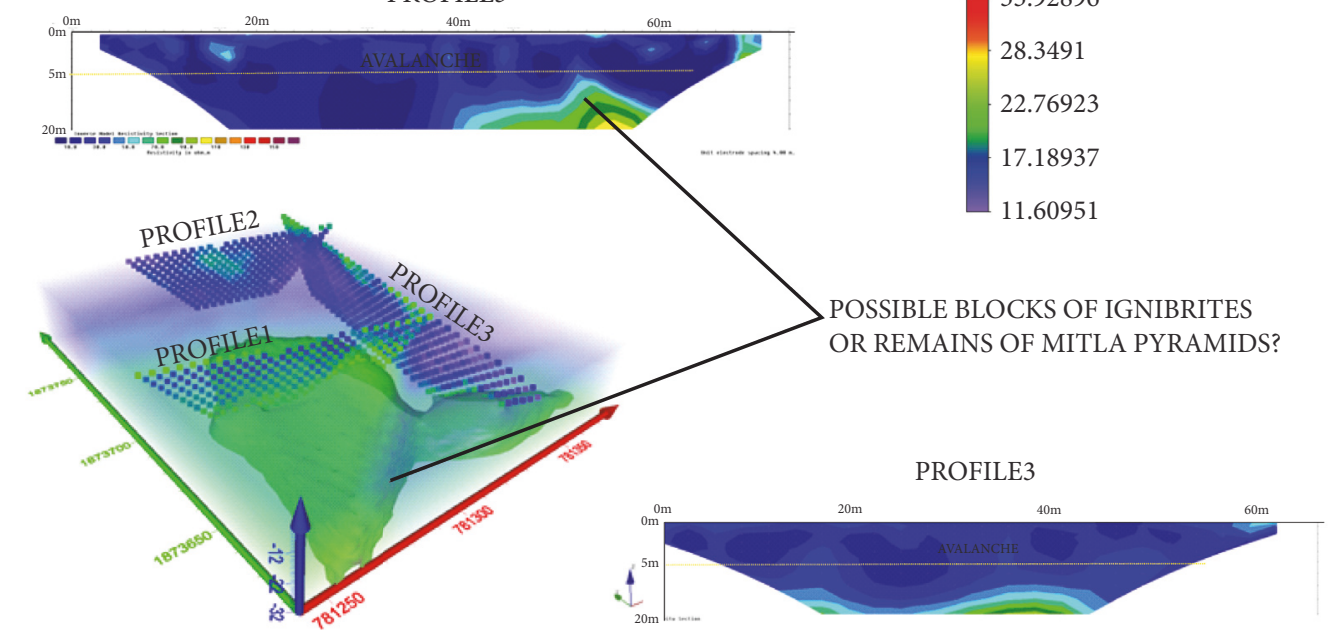

(b)

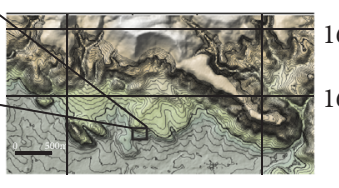

$16^{\circ} \mathrm{N} 57.5^{\prime}$

$16^{\circ} \mathrm{N} 56.5^{\prime}$

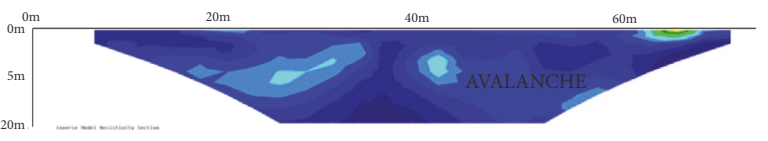

FIGURE 7: Results yielded by electrical tomography. Notable presence of an intermediate resistivity body (12) related to possible pyramid remains (green). The blue could correspond to landslide deposits. Where sections are located, there is the distribution of a 1 to $2,20 \mathrm{~m}$ thick distal landslide. (a) Location of the three geophysical profiles. (b) Location of the geophysical survey area on the avalanche front. (c) Geophysical profiles and 3D model.

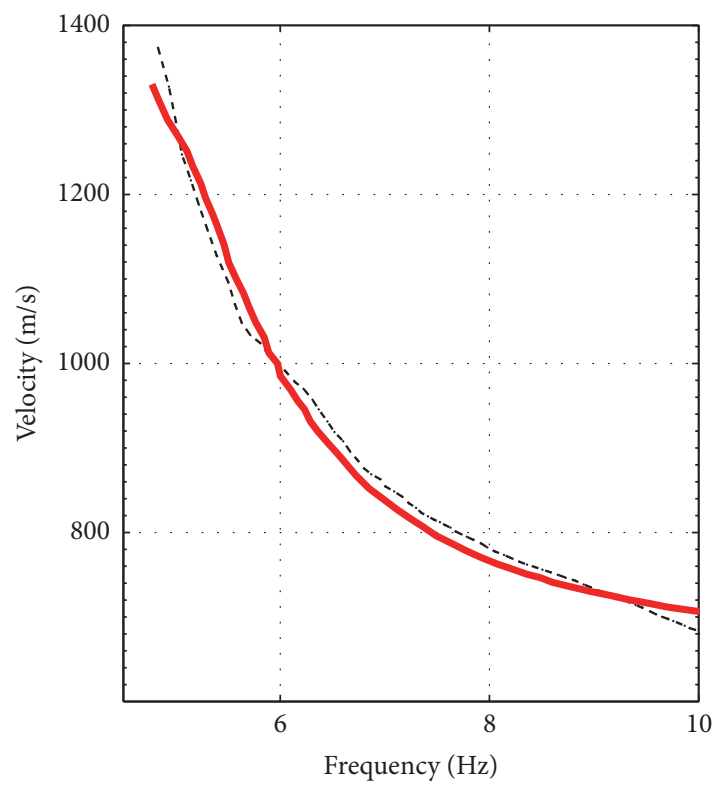

(a)

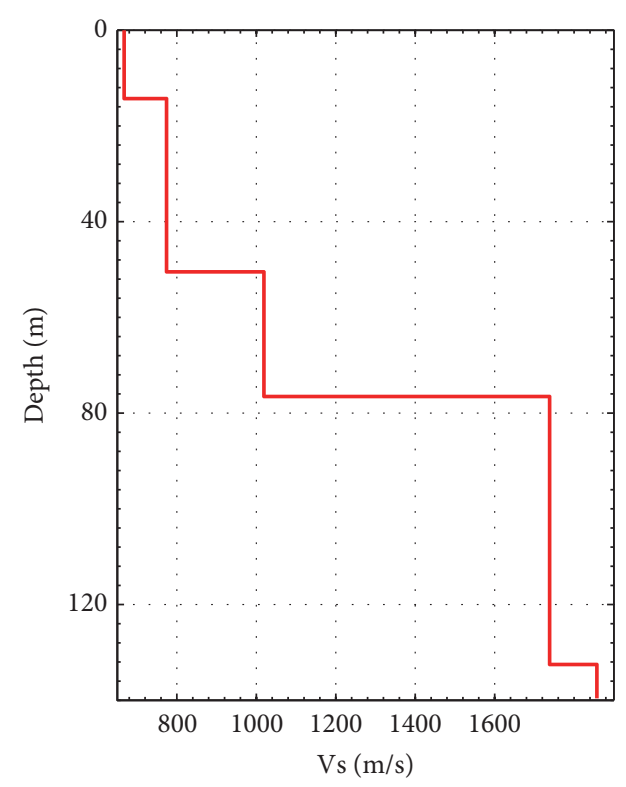

(b)

Figure 8: Seismic array \#1: (a) Rayleigh waves dispersion function. The red line corresponds to the first mode Rayleigh waves dispersion curve as best fit for the experimental values. (b) S-wave velocity model derived in this study. 


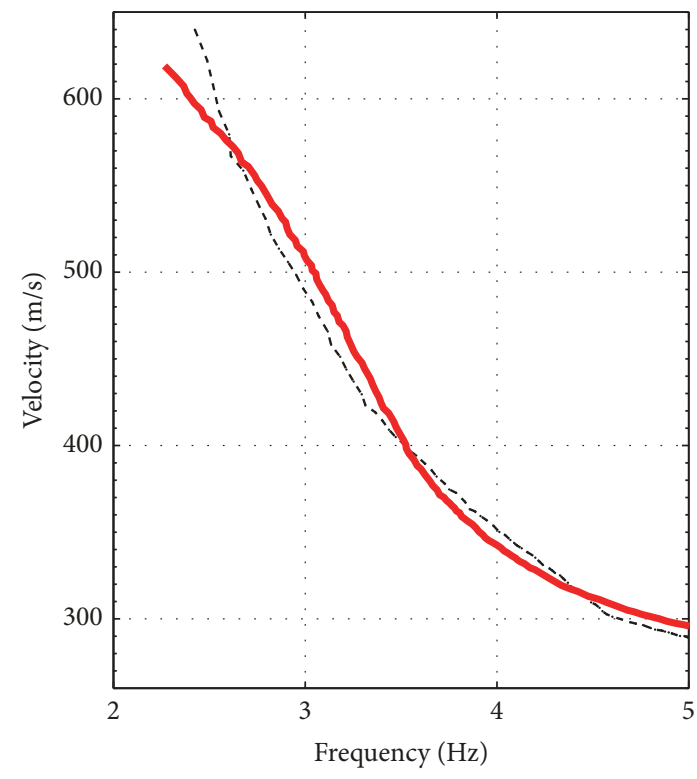

(a)

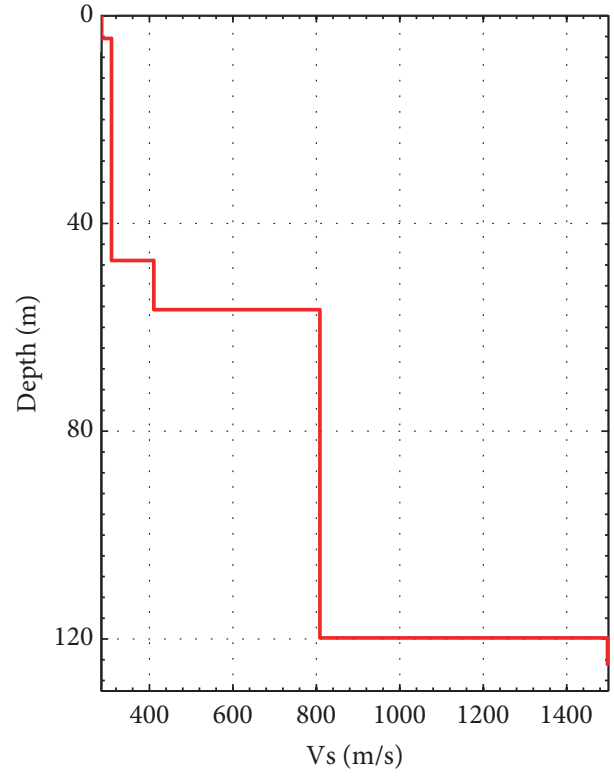

(b)

Figure 9: Seismic array \#2: (a) Rayleigh waves dispersion function. The red line corresponds to the first mode Rayleigh waves dispersion curve as best fit for the experimental values. (b) S-wave velocity model derived in this study.

TABLE 2: Dominant periods and classification of the type of soil for the seismic stations within the different arrays (http://www.nehrp.gov/).

\begin{tabular}{lcc}
\hline FREQUENCY & DOMINANT PERIOD & NEHRP CLASSIFICATION \\
\hline STATION 1. Array \#1 and array \#2 & & Solid Ground \\
\hline $3.17 \mathrm{~Hz}$ & $0.315 \mathrm{~s}$ & \\
\hline STATION 3. Array \#1 and array \#2 & & Solid Ground \\
\hline $3.35 \mathrm{~Hz}$ & $0.298 \mathrm{~s}$ & Rock \\
\hline STATION 4. Array \#1 & & $0.078 \mathrm{~s}$ \\
\hline $12.74 \mathrm{~Hz}$ & & Soft Ground \\
\hline STATION 2. Array \#2 & $0.833 \mathrm{~s}$ & \\
\hline $1.2 \mathrm{~Hz}$
\end{tabular}

archeological site of Mitla) and 70 meters below array 2 (north of the archeological zone).

Supporting these results, the northernmost site can be classified as ground softer than the southernmost site of the triangular arrangements. This can be correlated with the change in the landslide of Mitla.

\section{Discussion}

The Mitla avalanche opens a great discussion in the field of Geoarchaeology. The geological investigations give evidence that this event occurred in historical time that is during the Postclassic and before the arrival of the Spaniards. The important city of Mitla was found in decline during the arrival of the Spaniards.

The geophysical exploration data show important aspects, as the electrical tomography studies propose the existence of an important anomalous structure under the avalanche that could be part of the remains of the prehispanic Mitla. The elements that compose it were found between 5 and less of $20 \mathrm{~m}$ deep. On the other hand, with the earthquakes data and environmental noise, an avalanche thickness of $60 \mathrm{~m}$ was estimated, which allowed a correct calculation of the area and volume of the material removed (area of $2.79 \mathrm{~km}^{2}$ and volume of $0.1674 \mathrm{~km}^{3}$ ). In this same field of the relation between the volume or area removed by the collapse and the magnitude of the earthquake, two published works have been analyzed; one was by [35] and the other by [36]. Both make a great contribution to obtain the relationship between the destabilized areas and the Ms or Mw. However, in all these works they analyzed zones of Central America where the climate and the soils make up very different scenarios from Mitla. Consequently, it is likely that the magnitude proposed in our work does not correspond exactly to the real one, because the avalanche was in dry condition during the collapse, the geometries of the strata bedrock were not favorable to the destabilization, and the local climatic conditions have not allowed a great soils development. Anyway, here there is the morphological evidence that the Calaveras fault is part of an active fault system, as shown from the drainage networks that give the NNW-SSE structures a normal left-lateral component (Figure 2(c)). Despite these 

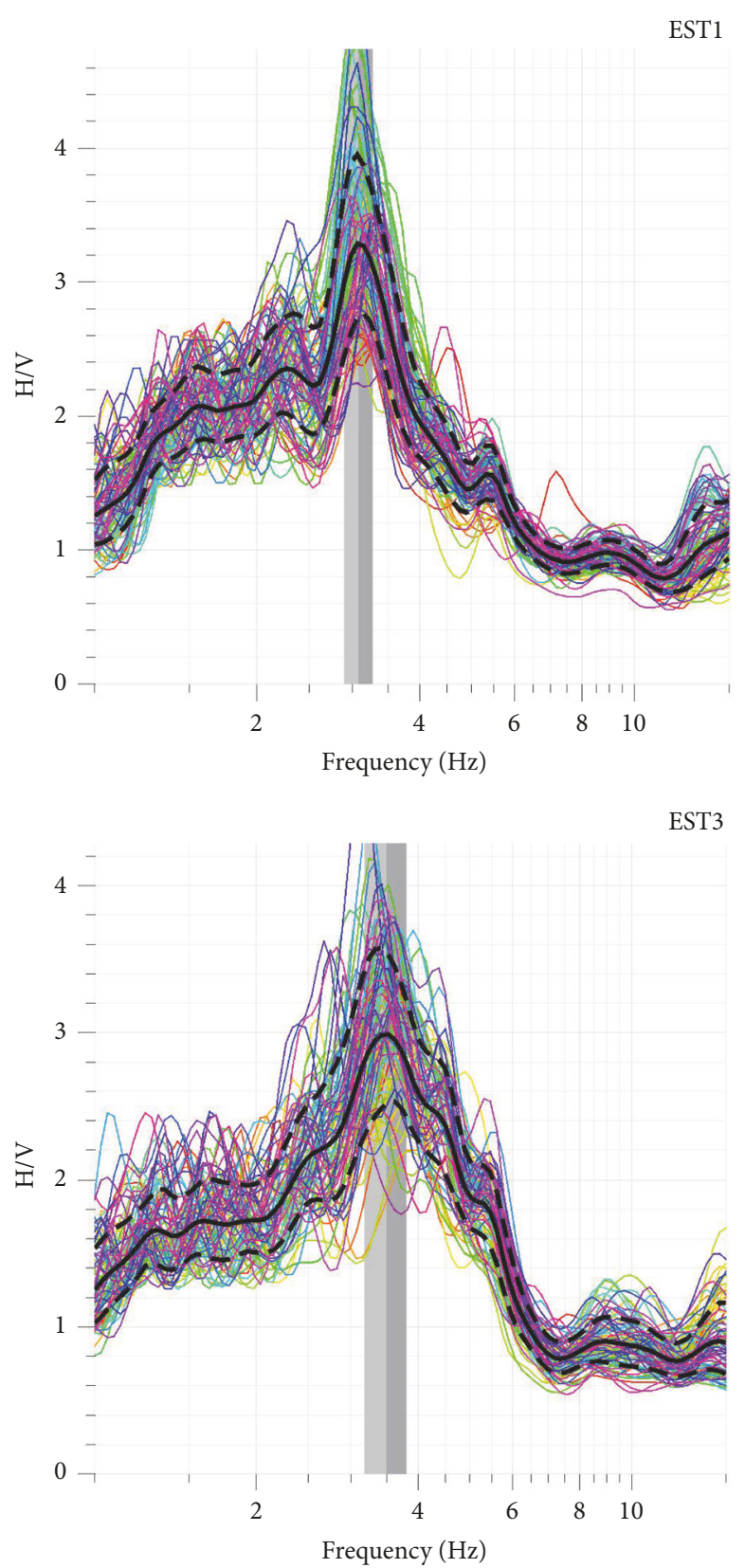

Figure 10: Examples of the H/V spectral ratio for two seismic sites.

differences, we have considered keeping Keefer's equation. In this paper we have only estimated the material volume of the Mitla avalanche. However, in later works we will make an estimate of the two avalanches that could have been generated by the same earthquake (Garduño-Monroy et al., in press)

Starting from a maximum volume of $0.1674 \mathrm{~km}^{3}$ for the landslide, the earthquake that caused the ground shaking up to the slope collapse could have had a maximum magnitude of 7.3 according to the relationship of $[35,36]$.

If we consider the length of the Calaveras fault (with a minimum length of $10 \mathrm{~km}$ and maximum of up to $40 \mathrm{~km}$, Figure 3), it would be potential to generate an earthquake of magnitude in the range of 6.2 to $6.9 \mathrm{Mw}$, based on the relations proposed by [37] or [38], respectively.

So then, two possible sources were feasible in the generation of this avalanche. The presence of the geodynamic framework of Oaxaca with the occurrence of earthquakes between 7 and $8 \mathrm{Mw}$ could suggest that a comparable event could have generated the studied avalanche. On the other hand, if we consider also the morphological evidence of the Calaveras fault, an earthquake between 6 and $7 \mathrm{Mw}$ could have easily generated an avalanche of this type if the fault was active in the period of the landslide event. Both scenarios are plausible, but now the most important thing is to see the possibility of starting new geoarchaeological explorations and 
consider that these segments of the Oaxaca fault system are active.

\section{Conclusions}

This research indicates that the Mitla Landslide is a collapsed body formed of ignimbrite blocks and matrix from the Sierra La Calavera. According to its morphology, the geotechnical characteristics, and the geophysical data interpretation, the landslide was provoked by an earthquake of a magnitude in the range from 6.2 to $7.3 \mathrm{Mw}$. The observations on the field suggest that the earthquake could have been caused by the La Calavera fault, which is a normal fault with small left component and is part of the Oaxaca fault systemoriented NNW-SSE to N-S. But we also do not rule out that this avalanche was instead generated by the frequent seismic activity of the Cocos plate. These geological facts (from regional to local tectonics), and the age of the landslide, could introduce a new scenario regarding seismic hazard in Oaxaca, because beside the intense seismic activity caused by the Cocos plate, more shallow earthquakes could also occur. On the other hand, the fact that the Mitla fault (Calaveras) is currently active indicates that many of the fault segments are favorably oriented to the current stress field.

There is no precise age established for the landslide occurrence; however, the event presumably damaged the pyramids of Mitla, and a large part of the pyramids are probably located under the avalanche deposit as evidenced by the outcomes of this preliminary investigation. Considering that if the population reached 10,000 individuals, the extension must have been larger than what can be implied by the current remains.

From the point of view of geophysical exploration, the method of electrical tomography and the study of earthquakes and environmental noise were good and promising tools in the Geoarchaeology field of research, even if the procedure can be better calibrated in synergy with other survey techniques. It was not the case of the use of Georadar that it failed to provide great information in the highdetail characterization of the local subsoil and materials discrimination in depth as necessary for this type of research. For future work it is recommended to make a thinner network with electrical tomography in parallel with seismic profiles.

\section{Data Availability}

All the geological and geophysical data have been generated by the authors of this work.

\section{Conflicts of Interest}

The authors declare that they have no conflicts of interest.

\section{Acknowledgments}

Funding to support this work came from the SEPCONACYT-CB-5222009-01-134151 project entitled "Tectonic, Paleoseismologic and Archeoseismologic study in Holocene to recent lakes of the Trans-Mexican Volcanic
Belt and the Jalisco block". We wish to thank all who were involved in the Cemie-Geo P-17 project for contributing to the results of this study during the course on Geophysic Methods. We are also grateful to the local government and the community of San Pablo Villa de Mitla for all the help provided. All the information relating to historical earthquakes in the Oaxaca state was provided by the SSN, whose personnel carried out also the seismic stations arrangement, maintenance, and data acquisition.

\section{References}

[1] A. M. Michetti, E. Esposito, L. Guerrieri et al., "Environmental seismic intensity scale-ESI 2007," Memorie Descrittive Della Carta Geologica D'Italia, vol. 74, no. 41, 2007.

[2] A. N. Mahgoub, N. Reyes-Guzmán, H. Böhnel, C. Siebe, G. Pereira, and A. Dorison, "Paleomagnetic constraints on the ages of the holocene malpaís de zacapu lava flow eruptions, michoacán (México): implications for archeology and volcanic hazards," The Holocene, vol. 28, no. 2, pp. 229-245, 2018.

[3] M. León Portilla, La Visión De Los Vencidos, Relaciones Indígenas De La Conquista, UNAM, 1959.

[4] V. H. Garduño-Monroy, J. L. Macías, A. Oliveros, and V. M. HernándezMadrigal, "Progress in seismic and archeoseismic studies in the zone of mitla, oaxaca," in Proceedings of the $3 \mathrm{rd}$ INQUA-IGCP-567 International Workshop on Active Tectonics, Paleoseismology and Archaeoseismology, Morelia, México, 2012.

[5] F. R. Zúñiga, G. Suárez, Á. Figueroa-Soto, and A. Mendoza, "A first-order seismotectonic regionalization of Mexico for seismic hazard and risk estimation," Journal of Seismology, vol. 21, no. 6, pp. 1295-1322, 2017.

[6] D. Melgar, A. Ruiz-Angulo, E. S. García et al., "Deep embrittlement and complete rupture of the lithosphere during the $\mathrm{M} \mathrm{w}$ 8.2 Tehuantepec earthquake," Nature Geoscience, vol. 1, 2018.

[7] C. M. Valdes, W. D. Mooney, S. K. Singh et al., "Crustal structure of oaxaca, mexico, from seismic refraction measurements," Bulletin of the Seismological Society of America, vol. 76, no. 2, pp. 547-563, 1986.

[8] M. Spranger, GEOLIMEX: Eine erste Geotraverse durch Sudmexiko; Auswertung des refraktions seismischen Profils [Ph.D. thesis], Christian-Albrechts University, Kiel, Germany, 1994.

[9] H. Jödicke, A. Jording, L. Ferrari, J. Arzate, K. Mezger, and L. Rüpke, "Fluid release from the subducted Cocos plate and partial melting of the crust deduced from magnetotelluric studies in southern mexico: implications for the generation of volcanism and subduction dynamics," Journal of Geophysical Research: Solid Earth, vol. 111, no. 8, Article ID B08102, pp. 122, 2006.

[10] A. Jording, L. Ferrari, J. Arzate, and H. Jödicke, "Crustal variations and terrane boundaries in Southern Mexicoas imaged by magnetotelluric transfer functions," Tectonophysics, vol. 327, no. 1-2, pp. 1-13, 2000.

[11] F. Corbo, Estudio de la subducción y su relación con la presencia de fluidos a partir de sondeos magnetotelúricos en el Bloque de Jalisco y Oaxaca [Ph.D. thesis], Centro de Geociencias, Universidad Nacional Autónoma de México, México City, México, 2013.

[12] J. O. Campos-Enriquez, F. Corbo-Camargo, J. Arzate-Flores et al., "The buried southern continuation of the OaxacaJuarez terrane boundary and Oaxaca Fault, southern mexico: 
magnetotelluric constraints," Journal of South American Earth Sciences, vol. 43, pp. 62-73, 2013.

[13] J. A. Arzate-Flores, R. Molina-Garza, F. Corbo-Camargo, and V. Márquez-Ramírez, "Low angle contact between the oaxaca and juárez terranes deduced from magnetotelluric data," in Geodynamics of the Latin American Pacific Margin, vol. 173, pp. 3357-3371, Birkhäuser, Cham, Switzerland, 2016.

[14] N. León, Lyobaa o Mictlan, Delegación Mexicana, México, 1901.

[15] I. Ferrusquía-Villafranca, J. A. Denison, R. E. Wilson, F. W. McDowell, and J. Solorio-Munguia, "Tres edades radiométricas oligocénicas y miocénicas de rocas volcánicas de las regiones de la mixteca alta y valle de oaxaca, estado de oaxaca," Boletín de la Asociación Mexicana de Geólogos Petroleros, vol. 26, pp. 249262,1974

[16] D. M. McCann and A. Foster, "Reconnaissance geophysical methods in landslide investigation," Engineering Geology, vol. 29, pp. 59-78, 1990.

[17] M. Nogoshi and T. Igarashi, "On the propagation characteristics of microtremors," Seismological Society of Japan, vol. 23, pp. 264-280, 1970.

[18] Y. Nakamura, "Method for dynamic characteristics estimation of subsurface using microtremor on the ground surface," Quarterly Report of RTRI (Railway Technical Research Institute) (Japan), vol. 30, no. 1, pp. 25-33, 1989.

[19] H. Okada, The Microtremor Survey Method, Society of Exploration Geophysics, Tulsa, Okla, USA, 2003.

[20] H. Arai and K. Tokimatsu, "S-wave velocity profiling by inversion of microtremor H/V spectrum," Bulletin of the Seismological Society of America, vol. 94, no. 1, pp. 53-63, 2004.

[21] P. Y. Bard, "Microtremor measurements: a tool for site effect estimation," in Proceedings of the Second International Symposium on the Effects of Surface Geology on Seismic Motion, vol. 3 , pp. 1251-1279, AA Balkema, 1998.

[22] A. Clemente-Chavez, F. R. Zúñiga, J. Lermo et al., "On the behavior of site effects in central Mexico (the Mexican volcanic belt - MVB), based on records of shallow earthquakes that occurred in the zone between 1998 and 2011," Natural Hazards and Earth System Sciences, vol. 14, no. 6, pp. 1391-1406, 2014.

[23] SESAME WP05, "Site effects assessment using ambient excitations. Optimum deployment strategy for array measurements," European Commission - Research General Directorate EVG1 CT 2000-00026 SESAME, SESAME European research project WP05- Deliverable D07.05, Geopsy was developed by Laboratoire de Geophysique Interne et Tectonophysique (LGIT) Grenoble, France and University of Potsdam, Germany, 2002.

[24] M. Wathelet, Array recordings of ambient vibrations: surface wave inversion [Ph.D. thesis], Liege University, 2005.

[25] K. Konno and T. Ohmachi, "Ground-motion characteristics estimated from spectral ratio between horizontal and vertical components of microtremor," Bulletin of the Seismological Society of America, vol. 88, no. 1, pp. 228-241, 1998.

[26] O. Kulhánek, Introduction to digital filtering in Geophysics, Elsevier Scientific Publishing Company, The Netherlands, 1976.

[27] K. Aki, "Space and time spectra of stationary stochastic waves, with special reference to microtremors," in Bulletin of the Earthquake Research Institute, vol. 35, pp. 415-456, Tokyo University, 1957.

[28] H. Flores-Estrella and J. Aguirre-González, "SPAC: an alternative method to estimate earthquake site effects in mexico city," Geofísica Internacional, vol. 42, no. 2, pp. 227-236, 2003.
[29] J. Aguirre González, M. Rodríguez González, and R. Vázquez Rosas, Memorias del XXIII Congreso Nacional de Mecánica de Suelos, Tuxtla Gutiérrez, Chiapas, 2006.

[30] R. D. Barker, "Electrical imaging and its application in engineering investigations," in Modern Geophysics in Engineering Geology, D. M. McCann, M. Eddleston, P. J. Fenning, and G. M. Reeves, Eds., vol. 12, pp. 37-43, Geological Society, 1997.

[31] D. Griffiths and J. Turnbull, "A multi-electrode array for resistivity surveying," First Break, vol. 3, no. 7, pp. 16-20, 1985.

[32] P. Stummer, H. Maurer, H. Horstmeyer, and A. G. Green, "Optimization of dc resistivity data acquisition: Real-time experimental design and a new multielectrode system," IEEE Transactions on Geoscience and Remote Sensing, vol. 40, no. 12, pp. 2727-2735, 2002.

[33] K. Hsu, "On sturzstroms-catastrophic debris streams generated by rockfalls," Geological Society of America Bulletin, vol. 86, no. 1, pp. 129-140, 1975.

[34] BSSC Program on Improved Seismic Safety Provisions, NEHRP Recommended Provisions for Seismic Regulations for New Buildings and Other Structures, Fema, 1998.

[35] D. K. Keefer, "Landslides caused by earthquakes," Geological Society of America Bulletin, vol. 95, no. 4, pp. 406-421, 1984.

[36] C. E. Rodríguez, J. J. Bommer, and R. J. Chandler, "Earthquakeinduced landslides: 1980-1997," Soil Dynamics and Earthquake Engineering, vol. 18, no. 5, pp. 325-346, 1999.

[37] S. G. Wesnousky, "Displacement and geometrical characteristics of earthquake surface ruptures: Issues and implications for seismic-hazard analysis and the process of earthquake rupture," Bulletin of the Seismological Society of America, vol. 98, no. 4, pp. 1609-1632, 2008.

[38] D. L. Wells and K. J. Coppersmith, "New empirical relationships among magnitude, rupture length, rupture width, rupture area, and surface displacement," Bulletin - Seismological Society of America, vol. 84, no. 4, pp. 974-1002, 1994. 

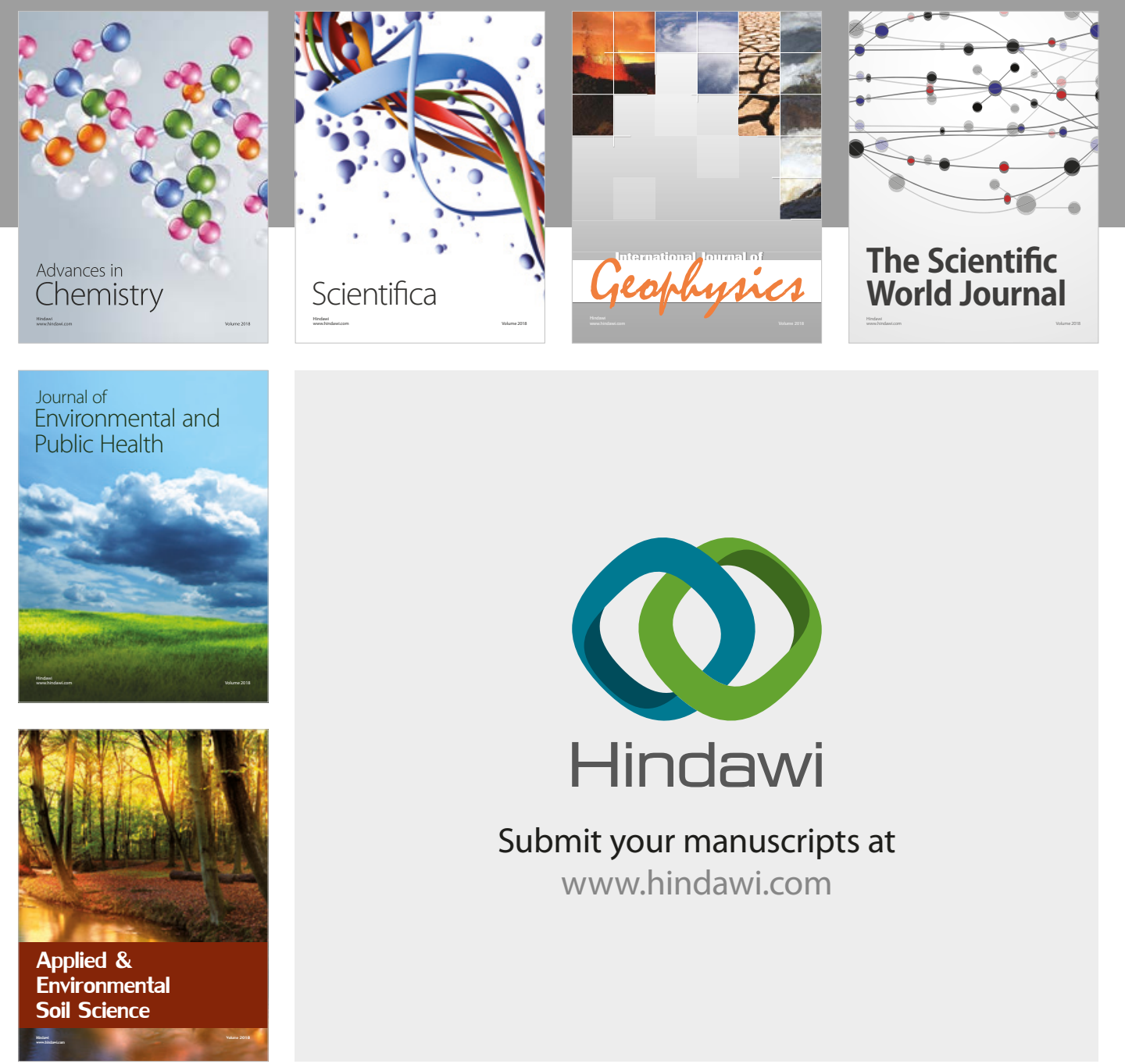

The Scientific

\section{World Journal}
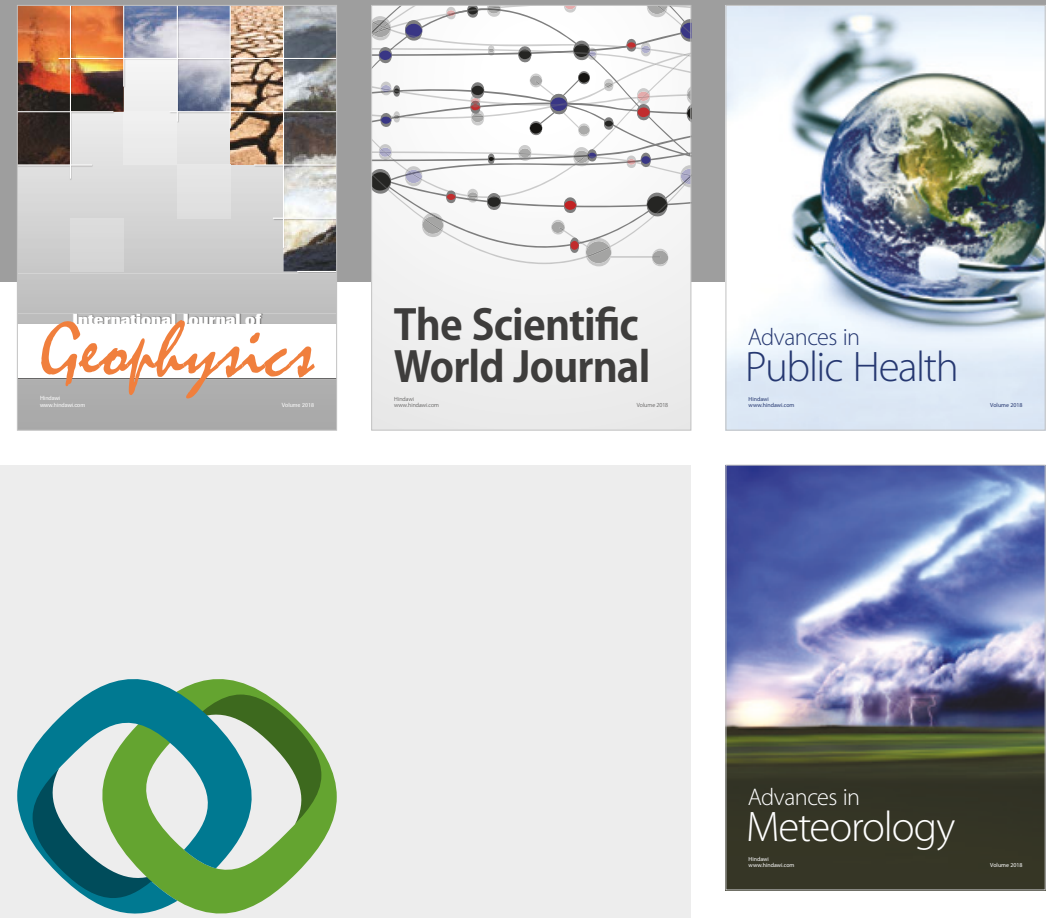

Advan

Public Health

\section{Hindawi}

Submit your manuscripts at

www.hindawi.com
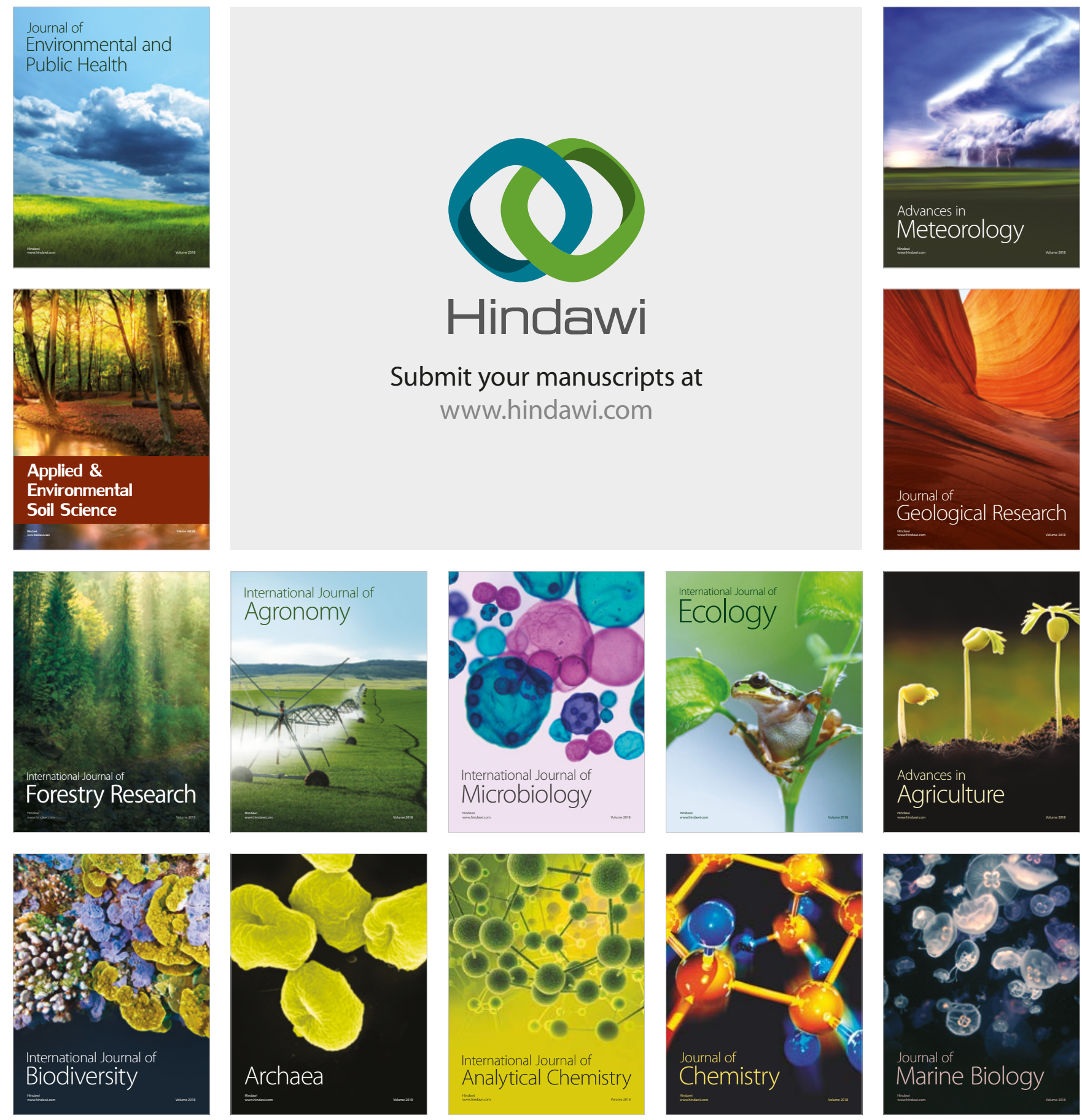